\title{
BEVOLKING EN MILIEU VAN ARUBA
}

\author{
'They took my knowledge \\ to heal the soul of the sick, \\ and the tool I built \\ to capture the very essence of God.' \\ Wilhelm Reich: The murder of Christ (1966)
}

Deze beschouwing is een poging mee te denken over Aruba's toekomst. De recente demografische- en economische ontwikkelingen worden belicht, waaruit aanknopingspunten volgen voor ruimtelijke ordening. Bij de bespreking van het milieu komt met name de vraag op, of inrichting van een natuurpark voor het eilandgebied wenselijk zou zijn.

Het gaat om de samenhang tussen de volgende drie elkaar wederzijds beïnvloedende grootheden: (1) de bevolking, (2) haar (economische) activiteiten in de productieve en consumptieve sfeer, (3) het eilandgebied. Veranderingen binnen de ene grootheid zullen de andere twee beïnvloeden, waarna terugwerking plaats vindt.

De voldoende diepe, natuurlijke havens, leidden in de twintiger jaren tot overslag en raffinage van aardolie, welke aanvankelijk uit Maracaibo (Venezuela) werd aangevoerd. Op de komst van de Lago raffinaderij, waarvan de constructie in 1929 werd voltooid, volgde een enorme immigratie. 'Boom town' San Nicolas breidde zich sterk uit. De levensstandaard steeg flink op het eiland, hetgeen zich manifesteerde in een op Amerikaanse ideeën geënt consumptiepatroon van de jongere generatie, alsmede in de opkomst van groot- en detailhandel. 
Het autobezit nam in de veertiger jaren sterk toe. Genoemde ontwikkelingen namen de noodzaak weg tot agrarische activiteiten die toch al te lijden hadden van geringe en wisselvallige regenval (fig. 1) en een vrijwel steeds doorstaande, harde passaatwind. In het hoofdstuk 'Eilandgebied' wordt de huidige keten van oorzaak en gevolg beschreven: het toerisme.

\section{DEMOGRAFIE}

Het Bureau voor de Statistiek te Willemstad, Curaçao, heeft in 1971 voor de regio Aruba een minimum- en maximumprognose van het bevolkingsaantal gegeven. Deze ziin voor januari 1985 respectievelijk 69.500 en 75.759 , cijfers welke voor de leek een exactheid suggereren, welke in werkelijkheid niet bestaat. De statistische massa van een kwart miljoen inwoners op de gehele Nederlandse Antillen is namelijk te gering voor lange-termijnprojecties (15 jaar vooruit). Daarenboven kan

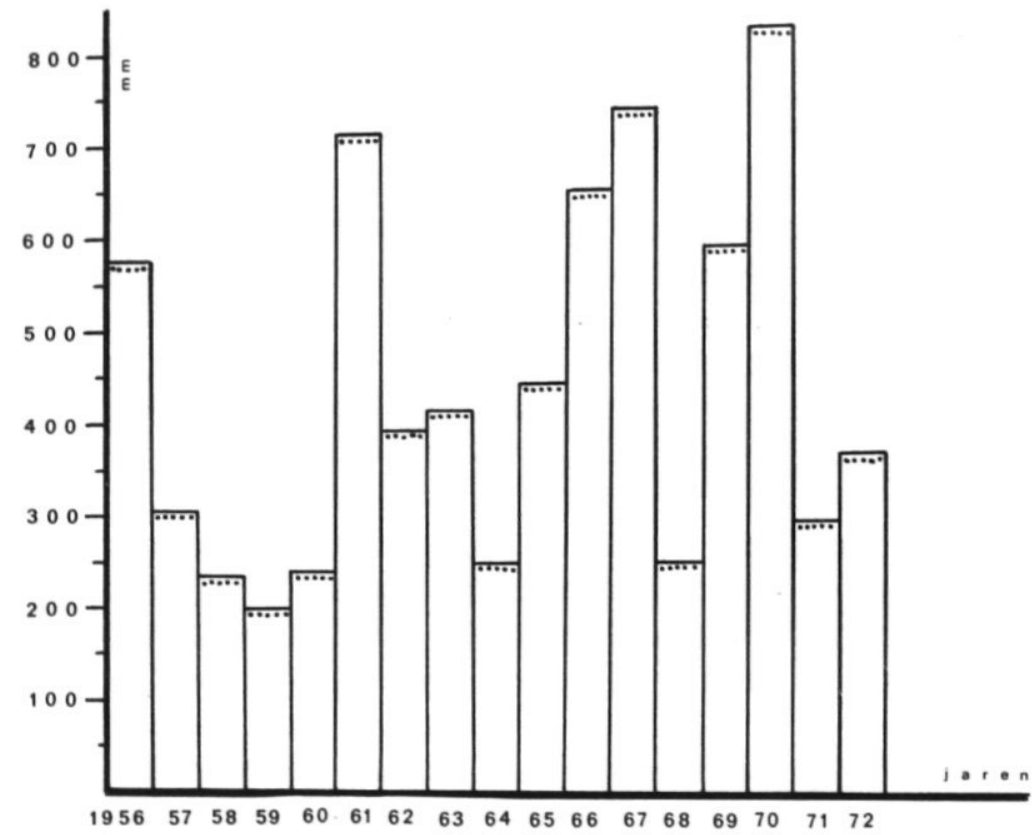

Fig. 1. Jaarlijkse hoeveelheid regen (in mm), gemeten op het station Balashi, Aruba, $1956 \mathrm{t} / \mathrm{m}$ 1972. (Uit: Water resources development program 1975). 
geen rekening worden gehouden met migratiebewegingen, omdat verhuizing binnen de zes Antilliaanse eilanden zich vanwege de gebrekkige registratie grotendeels aan statistische waarneming onttrekt. Tenslotte is door toenemend gebruik van anticonceptiemiddelen het verloop van de vruchtbaarheid moeilijk bepaalbaar.

Met behulp van een eenvoudig spreidingsdiagram wordt hier aannemelijk gemaakt dat de officiële ramingen voor Aruba véél te hoog liggen. De exponentiële bevolkingsgroei welke men zou verwachten, blijkt voor de beschouwde periode (19571975) niet op te gaan. Dit hangt samen met het feit, dat de groei zich heeft gestabiliseerd. De gedaante van de bevolkingspiramide voor het jaar 1974 ult $^{\circ}$ duidt eveneens in die richting. $\mathrm{Zij}$ is aan de voet versmald als gevolg van een geringer aantal geboorten dan voorheen. De beroepsbevolking zal tijdelijk nog sterk toenemen. In het rapport Bevolking en Arbeid, dat de Dienst voor Economische Ontwikkeling (D.E.C.O.) in augustus 1974 heeft gepubliceerd, is vermeld, dat alleen al vanwege deze groei er van 1973 tot 1978 ongeveer 4.000 arbeidsplaatsen dienen bij te komen. Eerst wordt nu de bevolkingspiramide gegeven (fig. 2), daarop volgt het spreidingsdiagram (fig. 3).

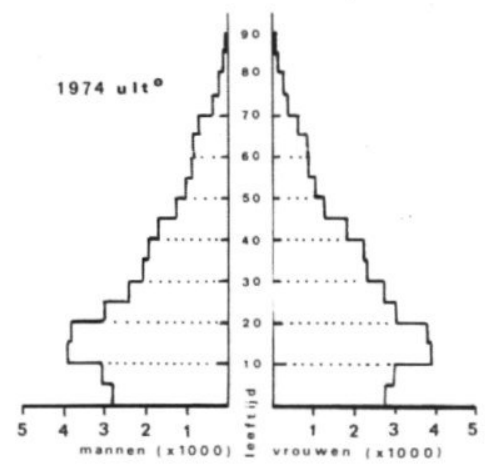

Fig. 2. Bevolkingspyramide van Aruba in het jaar 1975.

Het op zich toch wel merkwaardige fenomeen, dat de bevolkingsgroei bijna constant is in plaats van exponentiëel, verdient nadere analyse. In het kader van dit artikel is het wenselijk daarbij de bevolkingsaantallen te herleiden tot dichtheid 
TABEL

Inwonertal op Aruba ${ }^{1}$

\begin{tabular}{|c|c|c|c|}
\hline $\begin{array}{l}\text { Jaar } \\
\text { ult }^{\circ}\end{array}$ & Aantal & $\begin{array}{l}\text { Bev. dichtheid } \\
\text { per } \mathrm{km}^{2}\end{array}$ & Opmerkingen \\
\hline 1817 & 1.732 & 9 & 1824-1830 goudwinning \\
\hline 1850 & 3.054 & 16 & \\
\hline 1863 & 3.258 & 17 & 1874-1916 goudwinning \\
\hline 1900 & 9.702 & 50 & $\left.{ }^{2}\right)$ \\
\hline 1910 & 9.357 & 48 & \\
\hline 1920 & 8.265 & 43 & \\
\hline 1925 & 9.435 & 49 & 1924 komst Lago \\
\hline 1930 & 15.687 & 81 & 1929 start Lago-raffinaderij \\
\hline 1935 & 20.414 & 106 & \\
\hline 1940 & 30.614 & 159 & \\
\hline 1945 & 42.764 & 222 & \\
\hline 1950 & $51.000^{3}$ & 264 & \\
\hline 1955 & 55.483 & 287 & 1954 Talk of Town hotel $(64 \mathrm{~K})$ \\
\hline 1960 & 56.910 & 295 & 1959 Aruba Caribbean hotel $(220 \mathrm{~K})$ \\
\hline 1965 & 59.415 & 308 & \\
\hline 1970 & 60.734 & 315 & \\
\hline 1975 & 61.982 & 321 & hotelcap. gegroeid tot $1.500 \mathrm{~K}$ \\
\hline
\end{tabular}

1) het eiland heeft een opp. van $193 \mathrm{~km}^{2}$

$\left.{ }^{2}\right)$ zie grafiek 'Bevolkingsdichtheid per $\mathrm{km}^{2}$ op Aruba (fig. 4).

$\left.{ }^{3}\right)$ schatting

K kamers

per $\mathrm{km}^{2}$. In beginsel doet dit niets af aan de 'trend', omdat bij deze transformatie telkens door hetzelfde getal (193) wordt gedeeld. In bovenstaande tabel zijn de betreffende reeksen vermeld. Zie tevens figuur 4 en de verderop gegeven beschouwing.

Het in figuur 4 uitgezette verband tussen het aantal inwoners per vierkante kilometer en de tijd, benadert voor de jaren 1920 e.v. een S-vormige kromme met een buigpunt in de buurt van 160 op de verticale as. Gezien het symmetrisch verloop ten opzichte van het buigpunt, rijst het vermoeden, dat hier sprake is van een logistische groeikromme. Wiskundige toetsing van het cijfermateriaal bevestigt deze veronderstelling (fig. 5). Uit de theoretische berekening volgt hierin een maximaal bevolkingsaantal van 64.414 (334 per $\left.\mathrm{km}^{2}\right)$. 


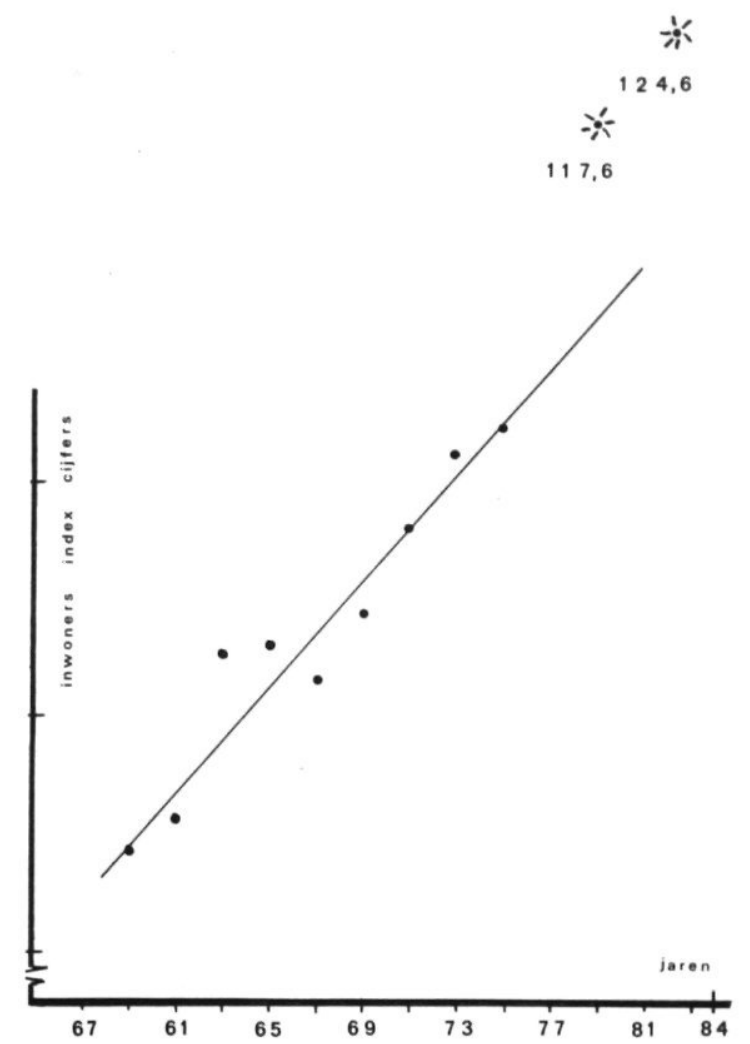

Fig. 3. Spreidingsdiagram van de bevolking van Aruba met prognoses voor 1979 en 1984.

\begin{tabular}{ccc} 
jaar ult $^{\circ}$ & inwoners & \multicolumn{1}{c}{ indexcijfers } \\
1957 & 55.806 & 100,0 (basisjaar) \\
1959 & 56.995 & 102,1 \\
1961 & 57.347 & 102,8 \\
1963 & 59.315 & 106,3 \\
1965 & 59.415 & 106,5 \\
1967 & 59.020 & 105,8 \\
1969 & 59.813 & 107,2 \\
1971 & 60.811 & 109,0 \\
1973 & 61.717 & 110,6 \\
1975 & 61.982 & 111,1 \\
1979 & 65.651 & 117,6 min. prognose $(*)$ \\
1984 & 69.513 & 124,6 min. prognose $(*)$ \\
1979 & 70.671 & 126,6 max. prognose \\
1984 & 75.759 & 135,8 max. prognose
\end{tabular}




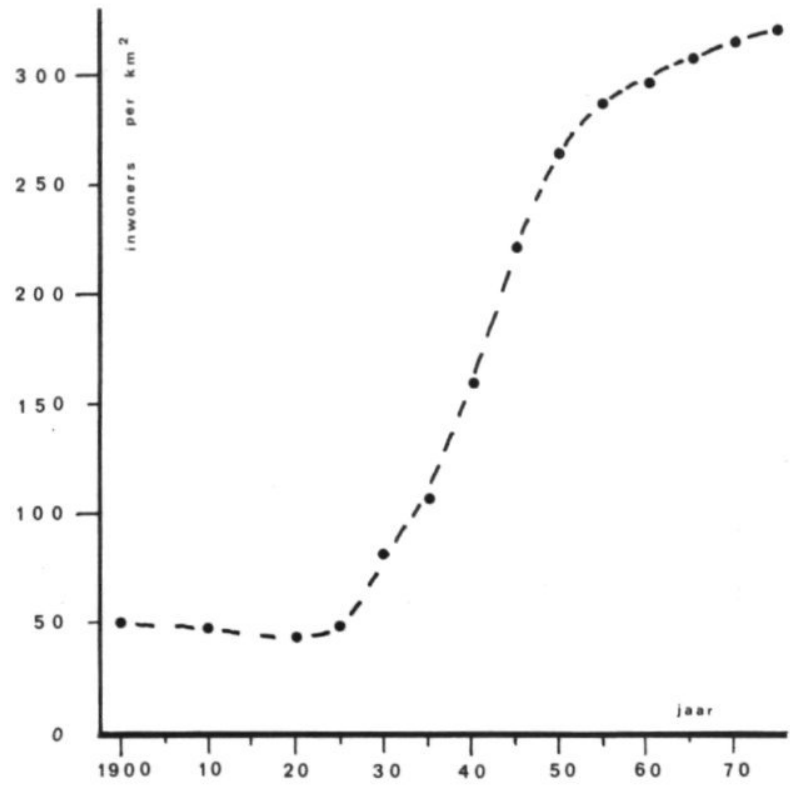

Fig. 4. Bevolkingsdichtheid per $\mathrm{km}^{2}$ op Aruba van 1900 tot 1975.

Wordt de berekeningsmethode voor de logistische curve welke door Erkelens (1968) als computerprogramma is ontwikkeld toegepast op de ontwikkeling van de bevolkingsomvang van Aruba, dan krijgen wij de volgende getallen.

$\begin{array}{rrr}\text { Jaar } & \text { Bevolking } & \text { Berekend } \\ & & \\ 1925 & 9.435 & 9.480 \\ 1930 & 15.687 & 14.980 \\ 1935 & 20.414 & 22.360 \\ 1940 & 30.614 & 31.100 \\ 1945 & 42.764 & 40.000 \\ 1050 & 51.000 & 47.800 \\ 1955 & 55.483 & 53.760 \\ 1960 & 56.910 & 57.880 \\ 1965 & 59.415 & 60.520 \\ 1970 & 60.734 & 62.140 \\ 1975 & 61.982 & 63.100 \\ & & \\ 1980 & & 63.660 \\ 1990 & & 64.170 \\ 2000 & & 64.330\end{array}$

De computerberekening ligt in de lijn van het eerder geconstateerde feit (fig. 2 en 4), dat de bevolking minder snel groeit dan voorheen en dat er voor de komende jaren een voortgezette vermindering van het aantal geboorten zal zijn. In dit verband is het van 
belang erop te wijzen, dat de logistische groeicurve wordt gehanteerd voor de beschrijving van de biologische groei. Bij biologische populaties constateert men wel eens, dat de groei aanvankelijk evenredig toeneemt met het aantal aanwezige exemplaren, maar later afneemt naar de mate dat de draagkracht van het milieu bereikt wordt.

Op het eivolle eiland, waar behalve de eigen bevolking eveneens een toenemend aantal buitenlandse gasten vertoeft, begint de beperkte ruimte zich te doen gevoelen. Behalve het groeiproces spelen eveneens vele andere factoren een rol, zoals mentaliteit en techniek. Infrastructurele voorzieningen, het scheppen van werkgelegenheid e.d. zullen ongetwijfeld het plafond in opwaartse richting verschuiven.

Het is opmerkelijk hoe snel de Arubanen hebben ingespeeld op de door de Stichting Famya Plania gepropageerde geboortebeperking. Vittachi (1977) wijdt aan dit onderwerp een arti-

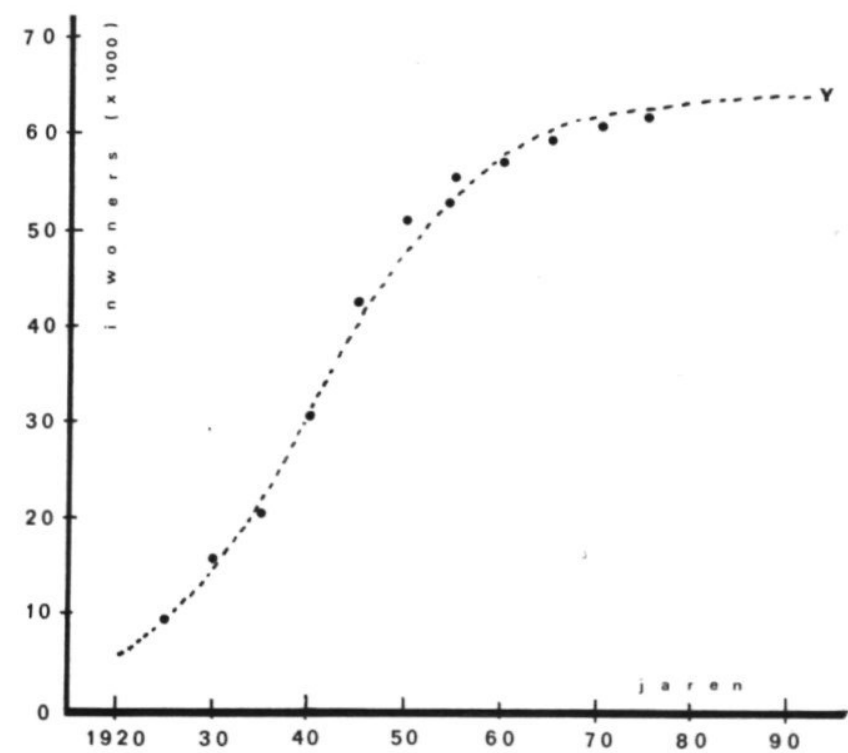

Fig. 5. Theoretische berekening van de ontwikkeling van de bevolkingsomvang op Aruba. 
kel, waarin wordt vastgesteld dat geboortebeperking-acties bij uitstek succes hebben op eilanden. Dit hangt samen met de goede bereikbaarheid van de bewoners. Ook het feit dat vrijwel iedereen in de onderzochte gebieden kan lezen en schrijven is een gunstige factor. In de huidige tijd worden de vruchten van de economische groei meer gelijkelijk verdeeld dan voorheen. De vrouwen nemen in toenemende mate deel aan het produktieproces, waardoor ze geneigd zijn eerst op latere leeftijd te trouwen, daarbij hun vruchtbare jaren in het huwelijk bekortend. De achtergrond van de dalende geboortecijfers op een aantal eilanden wordt mede gevormd door het onderwijssysteem in Westerse stijl. Werken op het land beschouwt men thans als onaantrekkelijk. Daarentegen wordt 'schoon' werk gezocht in de nijverheid, dienstensector of bij de overheid. Door het toenemend aanbod van de factor arbeid in genoemde sectoren, schiet de werkgelegenheid daar tekort. De negatieve sfeer welke de daaruit resulterende werklozen omgeeft, draagt onbewust bij tot vermindering van het aantal geboorten en tot emigratie.

Tabel 2 wijst op een waarschijnlijk sterk gevoelde bevolkingsdruk op Aruba, omdat het bruto geboortecijfer van dit eiland veel lager ligt dan die van de door Vittachi vermelde landen.

De gepresenteerde klassieke theorie van de groeicurve is voor demografische ontwikkelingen minder gefundeerd dan de moderne benadering door middel van leeftijdsklassen, vruchtbaarheid en sterfte. De logistische groeicurve geeft echter een aanschouwelijker beeld van wat aan de hand is, namelijk dat - gezien bevolkingsaantal plus toeristen - het jasje begint te knellen. Overigens zijn de resultaten niet in tegenspraak met die van de moderne onderzoeksmethode, voor de Nederlandse Antillen toegepast door mejuffrouw G.M. Antersijn (tab. 3).

In verband met de gesignaleerde ontwikkelingen in het bevolkingsaantal wordt ernstige twijfel uitgesproken over de voor het structuurplan gehanteerde bevolkingsprognose van resp. $67.000,72.000$ en 76.000 voor de jaren (ult ${ }^{\circ}$ ) 1978,1983 en 1988. Zie bladz. 20 van het Ruimtelijk Structuurplan (1975). 
TABEL 2

Bruto geboortecijfers (per 1.000 bevolking)

\begin{tabular}{l|ll}
\hline & \multicolumn{2}{|c}{ jaar } \\
Eiland $\left.{ }^{1}\right)$ & 1965 & 1974 \\
\hline Barbados & 26,1 & $20,8(1973)$ \\
Cuba & 35,0 & 25,0 \\
Fiji & 35,9 & 29,6 \\
Hong Kong & 28,8 & 19,3 \\
Mauritius & 35,4 & 27,5 \\
Singapore & 31,1 & 20,0 \\
Sri Lanka & 33,1 & $29,5(1972)$ \\
Trinidad \& Tobago & 32,8 & $26,5(1973)$ \\
\hline Aruba (32,6 in 1960) & 23,8 & $\left.16,1^{2}\right)$ \\
\hline
\end{tabular}

1) Vittachi 1977

2) Antersijn 1976 .

Het voorgaande doet vermoeden, dat de bevolkingsdruk thans reeds onacceptabel groot is. In dit verband wordt verwezen op toenemende criminaliteit en drankgebruik. Zo de cijfers hieromtrent, vermeld in tabel 4 en 5 , niet als een wetenschappelijk gefundeerde aanwijzing voor een te grote bevol-

TABEL 3

Omvang Arubaanse bevolking in het jaar 2.000 (volgens Antersijn 1976)

\begin{tabular}{|c|c|c|}
\hline hypothese & absoluut & $\begin{array}{l}\text { relatieve } \\
\text { toename }\end{array}$ \\
\hline $\begin{array}{l}1 \text { constante vruchtbaarheidsintensiteit van } 1,96 \text { en een con- } \\
\text { stante localisatie binnen leeftijdsgroepen }\end{array}$ & 81.622 & $32,25 \%$ \\
\hline $\begin{array}{l}2 \text { stijging vruchtbaarheidsinstensiteit tot } 2,1 \text { alsmede veran- } \\
\text { dering van de localisatie }\end{array}$ & 85.393 & $38,36 \%$ \\
\hline $\begin{array}{l}3 \text { constante vruchtbaarheid en constant migratiesaldo van } \\
-0,014.73 \text { (mannen) en }-0,009.63 \text { (vrouwen) }\end{array}$ & 60.070 & $-2,66 \%$ \\
\hline $\begin{array}{l}4 \text { stijging vruchtbaarheid naar stationaire niveau en constant } \\
\text { migratiesaldo van }-0,014.73 \text { (mannen) en }-0,009.63 \\
\text { (vrouwen) }\end{array}$ & 62.815 & $1,77 \%$ \\
\hline
\end{tabular}

Gezien het in de laatste decennia geconstateerde jaarlijkse vertrekoverschot, is een open systeem, ad. 3 en 4 , realistischer. 
kingsdichtheid mogen worden gebruikt, omdat namelijk gegevens voor het leggen van verband ontbreken, resp. nader onderzocht moeten worden, zijn de uitkomsten toch wel opvallend, waarbij in de minder dichtbevolkte districten blijkbaar niet minderalcoholisten voorkomen.

TABEL 4

Verdeling van de bevolking van Aruba over de wooncentra.

\begin{tabular}{l|rrrrrr}
\hline Woonkern & \multicolumn{1}{|c}{1953} & 1970 & 1971 & 1972 & 1973 & \multicolumn{1}{c}{1974} \\
\hline Oranjestad & 11.670 & 16.658 & 16.911 & 16.678 & 16.818 & 17.006 \\
San Nicolas & 20.664 & 16.211 & 15.901 & 16.037 & 15.962 & 15.749 \\
Santa Cruz & 8.977 & 8.609 & 8.725 & 8.783 & 8.892 & 8.751 \\
Savaneta & 4.910 & 8.099 & 8.126 & 8.244 & 8.320 & 8.486 \\
Noord & 4.823 & 6.524 & 6.652 & 6.726 & 6.921 & 6.924 \\
Paradera & 2.500 & 3.247 & 3.293 & 3.410 & 3.412 & 3.443 \\
Tanki Leendert & & 1.385 & 1.402 & 1.415 & 1.392 & 1.419 \\
\hline Woonkern & 1953 & $\%$ & 1970 & $(\%)$ & 1974 & $(\%)$ \\
\hline Oranjestad & 11.670 & 22 & 16.658 & 27 & 17.006 & 27.5 \\
San Nicolas & 20.664 & 39 & 16.211 & 27 & 15.749 & 25.5 \\
Buitendistrict & 21.210 & 39 & 27.864 & 46 & 29.033 & 47.0 \\
\hline Totaal & 53.544 & 100 & 60.733 & 100 & 61.788 & 100.0 \\
\hline
\end{tabular}

TABEL 5

Ontwikkeling van het inwonertal van Aruba.

Indexcijfers $(1970=100)$

\begin{tabular}{l|crrrr}
\hline & 1970 & 1971 & 1972 & 1973 & 1974 \\
\hline Oranjestad & 100 & 102 & 100 & 101 & 102 \\
San Nicolas & 100 & 99 & 99 & 98 & 97 \\
Buitendistricten & 100 & 101 & 103 & 104 & 106 \\
\hline
\end{tabular}

Opmerking: de relatief sterke groei van Noord $(1970=100,1974=106)$, hangt ongetwijfeld samen met de toenemende werkgelegenheid in de hotels.

Bovenstaande cijfers worden gebruikt in het onderdeel 'Eilandgebied'. 
TABEL 6

Misdrijven op Aruba - ter kennis van de politie gekomen

\begin{tabular}{l|cccc}
\hline & 1972 & 1973 & 1974 & 1975 \\
Totaal' & 1.558 & 1.909 & 2.032 & 1.941 \\
Index $(1972=100)$ & 100 & 123 & 130 & 125 \\
per capita: Aruba & $2,54 \%$ & $3,09 \%$ & $3,29 \%$ & $3,13 \%$ \\
\hline
\end{tabular}

Bron: Aruba Korps Politie Nederlandse Antillen, Commissariaat Aruba, Jaarverslagen 1973 en 1975.

TABEL 7

Alcoholgebruik per capita op Aruba in liters

\begin{tabular}{l|rlrlr}
\hline jaar & wijn & bier & sterke drank & gewogen & index cijfer \\
\hline 1950 & 1,0 & 26,7 & 7,3 & 72,5 & 100 \\
& & & & & \\
1962 & 1,3 & 21,2 & 9,4 & 80,2 & 111 \\
1963 & 1,2 & 20,4 & 8,0 & 70,8 & 98 \\
1964 & 1,1 & 17,9 & 9,0 & 74,1 & 102 \\
1965 & 1,2 & 18,0 & 7,0 & 62,4 & 86 \\
1966 & 1,3 & 19,9 & 10,9 & 87,9 & 121 \\
1967 & 1,5 & 24,4 & 9,7 & 85,6 & 118 \\
1968 & 1,5 & 29,7 & 8,5 & 83,7 & 115 \\
1969 & 1,7 & 36,4 & 8,5 & 90,8 & 125 \\
\hline
\end{tabular}

De geconsumeerde liters staan vermeld in Proc. first Aruban and Antillean Congress on Alcoholism. - Voor het Index cijfer is 1950 als basisjaar genomen. - Bij de bepaling van de Wegingsfactor is uitgegaan van het alcoholpercentage dat voor wijn, bier en sterke drank is gesteld op resp. $12 \%, 6 \%$ en $36 \%$.

Verdeling naar regio van alcoholisten: Buitendistricten $62 \%$. San Nicolas $16 \%$. Oranjestad 22\% (Proc. Congr. Alcoh.).
Buitendistricten $\quad 62 \%$
San Nicolas $\quad 16 \%$
Oranjestad $\quad 22 \%$ 


\section{ECONOMIE}

\section{Agrarische sector}

Vóór de komst van de aardolie-industrie kon een aloëboer zich een relatief goed inkomen verwerven. Nadien werd deze activiteit onaantrekkelijk, zoals trouwens landbouwbeoefening in het algemeen, gezien het lage gemiddelde dagloon in de primaire sector (tabel 7). Daarenboven is aloësnijden een bijzonder smerig en zwaar karwei. Pogingen om tot mechanisatie van het snijproces te komen zijn op niets uitgelopen. $\mathrm{Na}$ de vijftiger jaren daalden de exportprijzen voor aloëhars. Thans verbouwen nog slechts enkele oudere mensen de aloëplanten, zodat deze bedrijvigheid dreigt uit te sterven. Daardoor gaan bepaalde voordelen voor het eiland verloren, immers een aloëveld is een vorm van 'bebossing' alsmede een toeristische attractie. De Aloë Balm Fabriek te Oranjestad verwerkt het produkt tot cosmetica.

Medio 1967 bedroeg het beplante aloë-areaal 1.500 ha, waarvan 500 ha in exploitatie en daarvan weer 300 ha oogstbaar. In 1974 was nog slechts 150 ha oogstbaar. De gemiddelde, jaarlijkse export van de hars is overeenkomstig teruggelopen, waarbij variaties in de voorraden tot fluctuaties kunnen leiden.

Ook andere cultures zijn sinds 1924 verdwenen, zoals de vruchtbomen van Bubali. Van de totale economische activiteiten, gemeten naar arbeidsvolume, maakt de agrarische bedrijvigheid thans slechts $0,3 \%$ uit. Zie tabel 10 . Vrijwel alle voedings- en genotmiddelen, welke nodig zijn voor de lokale bevolking en voor de hotels, dienen geïmporteerd te worden. Sinds de aardoliecrisis van 1973 zijn de prijzen flink opge-

$\begin{array}{llll}\text { Jaar } & \text { Export }(\times 1.00 \mathrm{~kg}) & \text { Jaar } & \text { Export }(\times 1.000 \mathrm{~kg}) \\ 1908-34 & 395 \mathrm{gem} . \mathrm{p} / \text { jaar } & 1970 & 79 \\ 1939-42 & 260 \mathrm{gem} . \mathrm{p} / \text { jaar } & 1971 & 27 \\ 1962-66 & 75 \mathrm{gem} . \mathrm{p} / \text { jaar } & 1972 & 19 \\ 1969 & 73 & 1973 & 62\end{array}$


lopen, mede door de lange aanvoerwegen. In deze situatie wordt de behoefte gevoeld om méer op het eigen eiland te gaan produceren. Gedeputeerde Daniel Leo heeft in 1976 jonge Arubanen een agrarische opleiding in Colombia laten volgen. Bovendien stimuleert hij de aanleg van dammen en tanki's.

Het meest recente rapport op landbouwgebied, Water Resources Development Program van Finkel \& Finkel (Nov. 1975), geeft aan, dat op Aruba, afgezien van aloëvelden, ruim 2.000 hectare land tegen redelijke kosten geschikt gemaakt kan worden voor geïrrigeerde landbouw. Reeds 150 ha bebouwd met hoogwaardige groente en fruit, zouden kunnen voorzien in de totale lokale consumptie. Bij uitbreiding van de faciliteiten kan voldoende water worden vergaard voor bevloeiing van ongeveer 500 ha. De irrigatiekosten bedragen dan slechts $25 \%$ van het eindproduct. Finkel \& Finkel berekent een jaarlijkse opbrengst van N.A.F. 100.000 per ha, waarop N.A.F. 25.000 in mindering komt voor irrigatie, inclusief water- en bodemverbetering.

Door modernisering van de landbouw zou de economie iets minder eenzijdig worden. De importsubstitutie zou een niet onaanzienlijke deviezenbesparing opleveren. Per hectare is zo'n $1 \frac{1 / 2}{2}$ man nodig, derhalve in totaal 750 mensen, die successievelijk bij de verwezenlijking van het plan werk vinden, afgezien van indirecte werkgelegenheid. De overcapaciteit van de produktiefactor grond bedraagt liefst 350 ha. Deze kan worden aangewend voor verwerkende industrieën.

Wat van deze optimistische voorstelling van zaken ook waar moge zijn, het is een feit, dat de landbouw aanzienlijk kan worden verbeterd, indien de motivatie versterkt zou worden door de agrarische activiteit economisch aantrekkelijker te maken. Er zou dan behoefte kunnen ontstaan aan een landbouwschool, die dan jaarlijks ongeveer vijftig beoefenaren van het boerenbedrijf dient af te leveren. Daarnaast zijn dan nog nodig tuinlieden voor hotels en overheid, natuur- en milieubeheerders, bloemenhandelaren, aloëverbouwers, veehouders en vissers. Zo redenerend zou men voor de volgende decennia komen op jaarlijks 75 à 100 leerlingen. 
Bij dit alles vormt de motivatie de grootste beperkende factor: Begrijpelijk wanneer men zich de grote armoede herinnert van de agrariërs, die indertijd voor eigen gebruik produceerden. Wanneer aan bepaalde basale eisen wordt voldaan, zal voornamelijk in verhoging van de productiviteit van de grond door infrastructurele investeringen een stimulans voor de landbouw kunnen worden gevonden.

Op het Landbouwproefstation Santa Rosa - onder leiding van de heren T. Barmes en S. Vrolijk - kweekt men met succes allerlei groente: Aubergines, bonen, jambo, kalebas, komkommer, kool, kouseband, paprika, pepers, peterselie, selderij, spinazie, warmoes en wortelen. Voorts zijn er vele vruchtbomen. Vooral limoen, mango, mispel en sinaasappel beveelt men aan, omdat deze bomen weinig water vragen. De voor landbouw geschikte percelen zijn klein, doorgaans twee à drie hectare, hetgeen mechanisatie bemoeilijkt. Daarnaast is de wisselvallige, geringe neerslag (zie fig. 1) een handicap, alsmede de harde passaatwind, welke onbeschutte planten verwaait en het oppervlaktewater snel doet verdampen.

\section{Nijverheid}

Naar werkgelegenheid maakt de industrie, met inbegrip van de delfstoffenwinning, slechts $9,4 \%$ uit van het totaal, tegenover $23,4 \%$ in Nederland (Zie tabel 10 ). De zgn. stuwende bedrijfstakken, te weten agrarische sector, delfstoffenwinning en industrie, zijn derhalve zeer matig vertegenwoordigd, hetgeen betekent, dat de Arubaanse volkshuishouding vrijwel geheel drijft op aan het buitenland verleende diensten (toerisme) en op ontwikkelingshulp. De sector industrie bestaat - gemeten naar het aantal werknemers (tabel 9) - hoofdzakelijk uit chemie $(83 \%)$, dat wil zeggen de verwerking van aardolie. Overigens is de werkgelegenheid verbonden aan de steengroeven gerekend tot de dienstensector, namelijk transport.

De komst van de Lago Oil \& Transport Co. Ltd. in 1924 heeft een sterke toename van de bevolking tengevolge gehad. Aan het eind van de vijftiger jaren stagneerde de groei van de raffinaderij bij een capaciteit van 650.000 vaten per dag. De 
bevolking was in die periode juist flink toegenomen. Lago ging over tot diepte-investeringen, waardoor het aantal arbeidsplaatsen terug liep van 21.000 (1952) tot 6.200 (1965) en vervolgens tot 1.568 (1974). Dit verklaart het hoge percentage werklozen $(17,1 \%$ in 1972). Sindsdien gaven de sterke uitbreiding van het toerisme en de daarmee gepaard gaande - tijdelijke - bouwactiviteiten soelaas.

Tussen 1975 en medio 1977 heeft de Lago-raffinaderij op verminderde capaciteit gedraaid in verband met de tijdelijk teruggelopen vraag. Dit had zijn invloed op de eilandsontvangsten uit winstbelasting, welke van N.A. $f .45$ miljoen in 1974 zijn gedaald tot N.A.f. 35 miljoen in 1975. In tabel 10 is te zien, dat de werkgelegenheid in de industrie is afgenomen. In dezelfde tabel valt af te lezen, dat de openbare nutsbedrijven ruim twee keer zo zwaar wegen in het geheel als in Nederland. Dit houdt verband met het kleine gebied, dat toch haar voorzieningen nodig heeft. Het gevolg is, dat de utiliteitsbedrijven op een technisch suboptimale schaal dienen te worden opgezet. Het uit zee gewonnen leidingwater is ten ene male te kostbaar voor irrigatie. De bouwnijverheid heeft eveneens een zwaarder accent dan in Nederland. Opvallend zijn hier de grote schommelingen in werkgelegenheid. Door de bouw van hotels en grote projecten als het in 1976 opgeleverde ziekenhuis ontstaan pieken. Begrijpelijk is dat zo'n belangrijke sector $(13 \%$ in 1974) grote vraag uitoefent naar bouwmaterialen, waarop steenbrekers inspelen. Dit verklaart de schroom van de Overheid om de steenbrekers te verbieden hun bedrijf uit te oefenen - althans in bepaalde gebieden.

De vakverenigingen op het eiland zijn nog in opkomst, terwijl een consumentenbond om financiële redenen ontbreekt. Goed gefundeerde organisaties van waaruit de bevolking tegen natuurbederf zou kunnen protesteren ontbreken derhalve. Zo wordt steenbreek getolereerd, hoewel de opbrengst niet opweegt tegen de schade welke hierdoor aan het landschap wordt toegebracht. Daarnaast zal er ongetwijfeld een sterke druk bestaan tot het opzetten van nieuwe bouwprojecten, teneinde de werkloosheid $(10,2 \%$ tegenover $3 \%$ in Nederland in 1974 , af- 


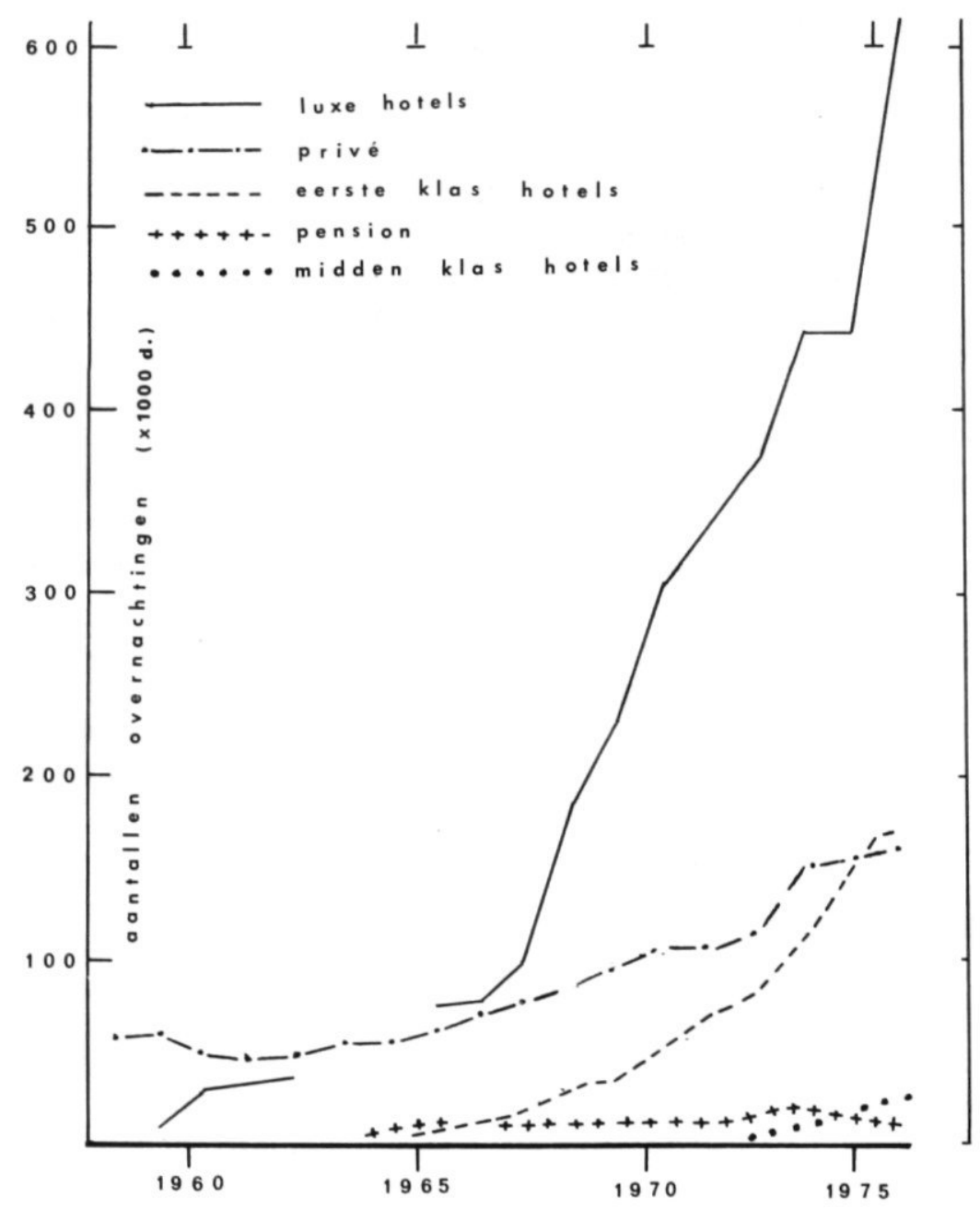

Fig. 6. Overnachtingen op Aruba. 
gezien van de enorme verborgen werkloosheid, overheid als werkverschaffer) tegen te gaan. In verband met het geografisch kleine gebied is ruimtelijke ordening dringend gewenst. Het Adviesbureau Arnhem heeft in mei 1975 een Ruimtelijk Structuurplan voor Aruba uitgebracht.

\section{Dienstensector}

Uit figuur 6 blijkt, dat het toerisme op Aruba sinds 1976 een geweldige vlucht heeft genomen, waarbij vooral de luxe- en eerste klas hotels een belangrijke rol hebben gespeeld. De cijfers voor 1976 wijzen uit, dat de groei nog steeds doorgaat.

Totaal bezoekers: 146.487 (128.852 in 1975: groei $13,7 \%)$ Overnachtingen: $\quad 1.023 .673(886.192$ in 1975 ; groei $15,5 \%)$

In 1976 deden daarenboven 121 cruisschepen Oranjestad aan tegenover precies 100 in 1975 . Voor oktober en november 1976 werd de bezettingsgraad in de hotels vastgesteld op respectievelijk 81 en 91 procent. Overigens stelt P.L. de Moulin, in zijn Schets voor een Ontwikkelingsplan Aruba (febr. 1976) vast, dat de toeristen minder besteden dan voorheen, althans dat de deviezeninkomsten uit het toerisme teruglopen, hetgeen duidt op een minder exclusief karakter er van. Meer dan voorheen doen chartervluchten, die meestal all-in zijn en in het land van herkomst worden voldaan, het eiland aan. Uitgaven op Aruba voor vervoer, logies, maaltijden e.d. worden dan niet gedaan door de toeristen, maar door de chartermaatschappijen.

Van het totaal aantal werknemers, vindt $39,5 \%$ emplooi in de bedrijfstak 'Handel en Horeca'. Binnen deze groep is bij de Handel het aantal manjaren (type werklieden) toegenomen van $3.031,0$ to $3.092,7$; een groei van $2 \%$. Het aantal in de Horecasector door werknemers gemakte uren is toegenomen van $1.735,7$ tot $1.956,4$ (12,7\% groei). De uitstralingseffecten van het toerisme op de overige sectoren zijn duidelijk waarneembaar. Zo is het aantal verloonde uren in de bedrijfstak vervoer en communicatie van 1972 op 1974 toegenomen met 30,34\% . Ook de bouwnijverheid floreert vanwege de hotelbouw, aanleg en verbetering van wegen, e.d. Dit beeld is eveneens terug te 
vinden in tabel 10, met als kengetal het vollediger begrip arbeidsvolume. De bouw en dienstensector liggen resp. 3,6 en 6,9 punten hoger dan in Nederland. $\mathrm{Al}$ met al schat men, dat ruim vijftig procent van de werkzame bevolking direkt of indirekt bij het toerisme is betrokken. F.A. Luidens heeft voor 1974 een multiplier-effect van het toerisme berekend van resp. 2,48 en 2,53 na een en twee jaren. In zijn rapport wijst hij op potentiële concurrentie, vooral op de mogelijkheid, dat Cuba haar grenzen opent voor de Noord-Amerikanen. Hij concludeert, dat diversificatie van de economie door agrarische- en industriële activiteiten zeer gewenst is.

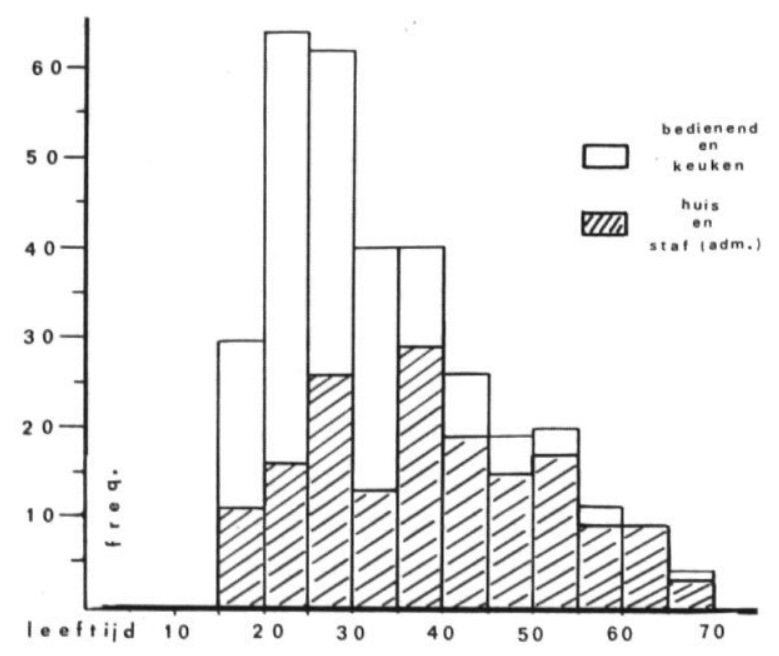

Fig. 7. Verdeling naar leeftijd van het personeel van het Aruba Caribbean Hotel in juli 1974. 
In het toerisme heeft gedurende de 70-er jaren een verschuiving plaats gevonden naar jongere leeftijdsklassen, die meer ondernemingslust hebben. Deze jongere groepen dient men extra vertier alsmede contact met Aruba's cultuur en natuur te bieden. De Moulin (1976) bepleit in zijn Schets de aanleg van een golfveld bij Malmok en het geschikt maken van de salinja voor zeilsport e.d. Ook noemt hij een plantentuin; daarvoor zou het betrekkelijk dichtbijgelegen terrein van Jaburibari uitermate geschikt zijn. De Moulin benadrukt ook het zoveel mogelijk handhaven van het exclusieve karakter van het toerisme; derhalve een teveel aan hotels in de beperkte kuststrook vermijden en zorgen dat het eiland niet ontaardt in een pretpark. Nodig is verhoging van het peil van het hotelpersoneel (hotelvakschool), en ondervanging van sociale verstoringen. Vooral de twee laatstgenoemde punten staan op de tocht. De Arubaanse jongeren hebben te weinig afleiding, waardoor ze in de hotels terecht komen. De moraal verslechtert. Maatregelen om minderjarigen uit de hotels te weren worden niet getroffen; jeugdprostitutie vindt plaats. Het politiejaarverslag van 1975 vermeldt, dat alles erop wijst, dat zowel de lokale als de internationale drughandel op Aruba blijft toenemen.

Wat het niveau van het hotelpersoneel betreft, is gebleken dat niet iedereen voor langere termijn voor werk in de hotels geschikt is. Met een hotelvakschool kan men hooguit de werknemers met aanleg kwalitatief verbeteren; voldoende aanleg en juiste mentaliteit zijn de eerste voorwaarden voor een goede ober of kok. Deze problemen spelen met name bij het bedienend- en keukenpersoneel. Uit grafieken van het hotelpersoneel, verdeeld naar leeftijd, blijkt, dat de hotels voor de bediening en de keuken jonge krachten aantrekken, terwijl de doorstroming naar oudere leeftijdsgroepen gering is. Dit houdt verband met psychologische drempels. Door het contact met veel uitgevende bezoekers en de goede salarissen die men verdient, raken veel obers, casinopersoneelsleden en barbedienden op een gegeven ogenblik aan de drank en vrouwen. Verliezen zij hun baan, dan merken zij, dat de hotelleiding aan goedkopere jonge krachten de voorkeur geeft. In fig. 7 is - voor een representatief hotel - duidelijk te zien, dat het huis- en 
TABEL 9

Werkgelegenheid op Aruba in 1972 en 1974

\begin{tabular}{|c|c|c|c|c|c|c|c|}
\hline \multirow{2}{*}{$\begin{array}{l}\text { I.S.I.C. } \\
\left.\operatorname{code}^{1}\right) \\
\text { (1) }\end{array}$} & \multirow{2}{*}{$\begin{array}{l}\text { Activiteit } \\
\qquad \text { (2) }\end{array}$} & \multicolumn{2}{|c|}{$\begin{array}{l}\text { Aantal } \\
\text { ondernemingen }\end{array}$} & \multicolumn{2}{|c|}{$\begin{array}{l}\quad \text { Werknemers } \\
\text { Type }^{2} \text { ) } \\
\text { werklieden }\end{array}$} & \multicolumn{2}{|c|}{$\begin{array}{l}\text { Gemiddeld } \\
\text { dagloon }\end{array}$} \\
\hline & & $\begin{array}{r}1972 \\
(3)\end{array}$ & $\begin{array}{r}1974 \\
(4)\end{array}$ & $\begin{array}{cc}1972 & 1 \\
(5) & \end{array}$ & $\begin{array}{l}1974 \\
(6)\end{array}$ & $\begin{array}{r}1972 \\
(7)\end{array}$ & $\begin{array}{r}1974 \\
(8)\end{array}$ \\
\hline . & $\begin{array}{l}\text { Landbouw, visserij } \\
\text { dranken/ } \\
\text { voedingsm. }{ }^{3} \text { ) } \\
\text { kleinindustrie } \\
\text { chemische } \\
\text { industrie }\end{array}$ & 7 & $\begin{array}{l}11 \\
24\end{array}$ & 21,0 & $\begin{array}{l}171,8 \\
182,7\end{array}$ & 10,17 & 13,27 \\
\hline III & Industrie & 47 & 50 & $2.107,9$ & $2.089,3$ & 55,89 & 58,84 \\
\hline IV & Utiliteitsbedrijven & 3 & 3 & 413,7 & 420,1 & 28,83 & 37,81 \\
\hline V & $\begin{array}{l}\text { Bouwnijverheid } \\
\text { groothandel } \\
\text { detailhandel } \\
\text { handel } \\
\text { restaurants e.d. } \\
\text { hotels, pensions } \\
\text { Horeca }\end{array}$ & 295 & $\begin{array}{r}60 \\
62 \\
236 \\
298 \\
73 \\
23 \\
96\end{array}$ & $3.031,0$ & $\begin{array}{r}2.736,3 \\
816,3 \\
2.276,4 \\
3.092,7 \\
428,0 \\
1.528,4 \\
1.956,4\end{array}$ & & \\
\hline VI & $\begin{array}{l}\text { Handel en horeca } \\
\text { vervoer } \\
\text { diensten m.b.t. } \\
\text { verv. }\end{array}$ & 383 & $\begin{array}{r}394 \\
16 \\
13\end{array}$ & $4.766,7$ & $\begin{array}{r}5.049,1 \\
347,6 \\
168,8\end{array}$ & 14,01 & 17,03 \\
\hline VII & $\begin{array}{l}\text { Vervoer \& } \\
\text { communicatie } \\
\text { fin. instellingen } \\
\text { zakelijke diensten }\end{array}$ & 30 & $\begin{array}{l}29 \\
23 \\
43\end{array}$ & 396,2 & $\begin{array}{l}516,4 \\
412,9 \\
214,7\end{array}$ & 20,48 & 23,20 \\
\hline VIII & $\begin{array}{l}\text { Bank- en } \\
\text { verzekeringsw. } \\
\text { medische- e.d. } \\
\text { dienst. } \\
\text { liefdadigh./ } \\
\text { vakverg. } \\
\text { partic. onderw./recr } \\
\text { reparaties/pers. } \\
\text { dienst. }\end{array}$ & re. & $\begin{array}{l}35 \\
\\
27 \\
32 \\
\\
34\end{array}$ & 538,2 & $\begin{array}{l}717,3 \\
118,6 \\
333,9 \\
153,7\end{array}$ & 20,69 & 23,18 \\
\hline IX & Dienstverlening & 119 & 128 & $1.054,1$ & $1.323,5$ & 14,17 & 14,64 \\
\hline $1-1 \lambda$ & Totaal & 701 & 737 & $11.314,81$ & $12.793,4$ & 23,43 & 26,29 \\
\hline
\end{tabular}

1) International Standard Industrial Classification.

$\left.{ }^{2}\right)$ Het arbeidsvolume wordt uitgedrukt in 'typewerklieden'; 1 type werkman is 260 verloonde dagen bij een 5-daagse werkweek en 312 bij een 6-daagse.

$\left.{ }^{3}\right)$ Inspringend om aan te geven, dat het subtellingen betreft $(11+24+15=50$, zie Industrie)

Bron: Statistiek Arbeidsvolume en Loonsommen 1972. De cijfers voor 1974 zijn nog niet elders gepubliceerd. 
administratief personeel meer normaal verdeeld is over de leeftijdsklassen dan het bedienend en keukenpersoneel. Wel dient rekening gehouden te worden met het feit, dat het hier een jonge bedrijfstak betreft. Het oudste luxe hotel, Aruba Caribbean, bestaat pas achttien jaar, sinds 1959. Op Bermuda, bij voorbeeld, kent men al zestig jaar toerisme. Al met al schijnt het reservoir, waaruit men hotelpersoneel put, voor Aruba beperkt.

TABEL 8

Verblijfstoeristen op Aruba naar herkomst in percentages; jaar 1975

\begin{tabular}{|c|c|c|c|c|c|c|}
\hline \multirow[b]{2}{*}{ Landen } & \multirow[b]{2}{*}{ Totaal } & \multirow[b]{2}{*}{ luxe } & \multicolumn{2}{|c|}{ Hotels } & \multirow[b]{2}{*}{ 3e klas } & \multirow{2}{*}{$\begin{array}{l}\text { particu- } \\
\text { lieren }\end{array}$} \\
\hline & & & 1e klas & 2e klas & & \\
\hline U.S.A./Canada & 69 & 75 & 81 & 12 & 21 & 26 \\
\hline Latijns Amerika & 28 & 23 & 16 & 83 & 75 & 59 \\
\hline Overige & 3 & 2 & 3 & 5 & 4 & 15 \\
\hline Totaal & 100 & 100 & 100 & 100 & 100 & 100 \\
\hline $\begin{array}{l}\text { waarvan } \\
\text { Venezuela }\end{array}$ & (19) & $(18)$ & (9) & (53) & (33) & $(32)$ \\
\hline
\end{tabular}

Met de opening van het Concorde hotel wordt blijkens tabel 11 de capaciteit van de op Palm Beach geconcentreerde luxe hotels met liefst vijftig procent uitgebreid. Gevreesd moet worden, dat een tekort aan vaklieden ontstaat, waardoor enerzijds de exploitatiekosten zullen toenemen vanwege de loonfactor, en anderzijds de kwaliteit van de geboden diensten zal verminderen. Tenslotte wordt nog aan de hand van tabel 8 gewezen op het gespreide en enigszins dualistisch karakter van de markten waarop men zich richt. Ongeveer $1 / 3$ van de luxe toeristen zijn 'emotionele' Latino's tegenover de meer 'nuchtere' Noordamerikanen. 
TABEL 10

Arbeidsvolume ${ }^{1}$ op Aruba in 1972, 1973 en 1974 (vergelijking \% 1974 met Nederland)

\begin{tabular}{l|rrrrrrrr}
\hline & \multicolumn{4}{|c}{ Type } & werklieden & \multicolumn{4}{c}{ Percentage } & Aruba & Ned.\% \\
Sectoren & 1972 & 1973 & 1974 & 1972 & 1973 & 1974 & 1974 \\
\hline Landb./tuinb./veeteelt & 52 & 52 & 57 & 0,3 & 0,2 & 0,3 & 6,3 \\
Industrie $^{2}$ & 2.146 & 2.128 & 2.127 & 10,2 & 9,9 & 9,4 & 23,4 \\
Utiliteitsbedrijven $^{\text {Bouwnijverheid }}$ & 414 & 411 & 420 & 2,0 & 1,9 & 1,9 & 0,9 \\
Dienstverlening $^{2.224}$ & 4.012 & 2.943 & 10,6 & 18,7 & 13,0 & 9,4 \\
Overheid $^{3}$ & 10.798 & 11.251 & 11.503 & 51,4 & 52,2 & 51,1 & 44,2 \\
Arbeidsreserve $^{4}$ & 2.891 & 2.746 & 3.186 & 13,8 & 12,7 & 14,1 & 12,8 \\
\hline Totaal & 2.460 & 936 & 2.306 & 11,7 & 4,4 & 10,2 & 3,0 \\
\hline
\end{tabular}

1) Arbeidsvolume omvat méér dan werknemers (tabel 9), namelijk zelfstandige bedrijfshoofden, medewerkende gezinsleden, werknemers.

2) Incl. delfstoffenwinning.

${ }^{3}$ ) Excl. Water en Energiebedrijf (zie Utiliteitsbedrijven). - De fluctuaties bij de Overheid hangen samen met de wisselende bouwactiviteiten, in die zin, dat de Overheid afvloei daaruit enigszins opvangt.

${ }^{4}$ ) Werkloosheidspercentage t.o.v. de beroepsbevolking.

\section{EILANDGEBIED}

In de inleiding is aangegeven hoe de natuurlijke omstandigheden de raffinage en overslag van aardolie mogelijk maakten, waardoor de bevolking, haar activiteiten en daardoor weer het gebied een totaal andere aanblik kregen. Voor toerisme gunstige omstandigheden zijn gecreeërd. De bevolking heeft immers dankzij de aanwezigheid van Lago goed onderwijs ontvangen, zij werd welvarend, waarbij detail- en groothandel gestalte kregen. Men heeft zich de Engelse taal eigen gemaakt en deels Amerikaanse denkwijzen overgenomen. Omdat het Amerikaanse bedrijf Lago sinds 1952 arbeidsbesparende technieken heeft geïntroduceerd, zijn veel werknemers afgevloeid, zodat ruimschoots voldoende arbeidskrachten beschikbaar waren om de hotels te bouwen en te bemannen.

De brede, witte stranden en het zonnige. tropische klimaat, dat door de vrijwel steeds heersende passaatwind geen extreem hoge temperaturen kent, maken het eiland zeer aantrekkelijk 
voor vacantiegangers. In 1959 verrees het eerste, grote, luxe hotel op Palm Beach. Na 1967 breidde de hotelaccomodatie zich snel uit, zoals tabel 11 laat zien. In het navolgende wordt ingegaan op de gevolgen van de geschetste ontwikkelingen voor het natuurlijk milieu, welke op haar beurt weer het denken en handelen van de bevolking zullen beïnvloeden.

In tabel 1 kan men aflezen, dat de bevolking sinds 1920 ruim verzevenvoudigd is. De toenemende welvaart heeft het autobezit en de woningbouw gestimuleerd. De droom van vrijwel iedere Arubaan is het bezit van een eigen huis, dat hij in vele gevallen zelf bouwt met hulp van familie en kennissen. Rond Oranjestad en ten westen van San Nicolas heeft suburbanisatie plaatsgevonden. Naast het stedelijk ruimtegebrek speelt de trek uit de stad een rol. De toegenomen mobiliteit maakt het mogelijk om een eensgezinswoning op het platteland of in een van de vele kleine buurtgemeenschappen te betrekken.

Op grote schaal vindt lintbebouwing plaats, waardoor achterliggende gronden geïsoleerd raken. Om al die verspreide gezinnen van water te voorzien, plaatst de overheid - uit zuinigheidsoverwegingen - kolossale, onesthetisch aandoende watertanks op diverse heuvels, zoals recentelijk te Jaburibari, waardoor de horizon is bedorven.

Het spanningsveld tussen verstedelijking, natuur en landschap, en (potentiële) landbouw is evident. Het onttrekken van grondwater door Shell op het zustereiland Curaçao, werd vroeger slechts door enkele vooruitziende geesten als een ernstig bezwaar gevoeld. Nu men aldaar de landbouw wil activeren vormt de lage grondwater spiegel een ernstig nadeel. In de Arubaanse buurtgemeenschap Noord heeft men in 1976 volkswoningen gebouwd op schaarse voor landbouw geschikte gronden. Het bestemmen van goede landbouwgronden voor huizenbouw zal thans niet zozeer als een gemis worden gevoeld, omdat de agrarische sector (blijkens Tabel 10) vrijwel niet bestaat. Daar zou evenwel verandering in kunnen komen indien door toepassing van moderne technieken en irrigatiesystemen de landbouw zou kunnen worden bevorderd. 
TABEL 11

Hotels op Aruba

\begin{tabular}{|c|c|c|c|c|c|c|}
\hline \multirow[b]{2}{*}{ Begin } & \multirow[b]{2}{*}{ Hotel } & \multirow[b]{2}{*}{ Locatie } & \multirow[b]{2}{*}{ Aard } & \multirow[b]{2}{*}{ Kamers } & \multicolumn{2}{|c|}{$\begin{array}{l}\text { Gem. bezetting } \\
\text { (\%) }\end{array}$} \\
\hline & & & & & 1974 & 1975 \\
\hline $6-1959$ & Aruba Caribbean & Palm Beach & luxe & 220 & 80,5 & 75,2 \\
\hline $3-1968$ & Aruba Sheraton & Palm Beach & luxe & 200 & 80,6 & 70,7 \\
\hline 3-1969 & Holiday Inn & Palm Beach & luxe & 400 & 84,7 & 73,4 \\
\hline \multirow[t]{2}{*}{$5-1975$} & Americana & Palm Beach & luxe & 200 & & \\
\hline & & & & 1.020 & & \\
\hline 1978 & Concorde & Palm Beach & luxe & 502 & & \\
\hline 1978 & Melia & Palm Beach & luxe & 450 & & \\
\hline \multirow[t]{2}{*}{1978} & Play Boy & Palm Beach & luxe & 320 & & \\
\hline & & & & 1.272 & & \\
\hline 1954 & Talk of the Town & Oranjestad & le kl. & 64 & 78,7 & 72,3 \\
\hline $2-1957$ & Basi Ruti & Palm Beach & le kl. & 15 & 65 & 48,5 \\
\hline $12-1966$ & Manchebo Beach & Eagle Beach & le kl. & 72 & 77,8 & 70,7 \\
\hline $7-1969$ & Divi Divi & Eagle Beach & le kl. & 148 & 88,2 & 82 \\
\hline \multirow[t]{2}{*}{$1-1975$} & Tamarijn Beach & Eagle Beach & le kl. & 100 & & \\
\hline & & & & 399 & & \\
\hline $9-1959$ & Astoria & S. Nicolas & comm. & 10 & & \\
\hline $9-1964$ & Central & Oranjestad & comm. & 25 & & \\
\hline $12-1964$ & Cactus Inn & Oranjestad & comm. & 21 & & \\
\hline \multirow[t]{2}{*}{$4-1970$} & Victoria & Oranjestad & comm. & 30 & & \\
\hline & & & & 86 & & \\
\hline
\end{tabular}

Het enorm gegroeide bevolkingsaantal, gecombineerd met de sterk vergrote mobiliteit en een toenemend vrij besteedbaar inkomen, heeft geleid tot een grote behoefte aan mogelijkheden tot recreatie. Gezien de vorm van de bevolkingspiramide (zie figuur 1) is voor de nabije toekomst een toenemend aantal jonge gezinnen te verwachten, die vanwege hun kleine kinderen vooral ontspanning in de open lucht zullen zoeken. 
Vroeger voelden 'de Arubanen' zich niet bijzonder tot zwemmen en strandbezoek aangetrokken. Onder invloed van de zonminnende toeristen is daar evenwel verandering in gekomen. Vooral de jeugd trekt graag naar het strand om te zwemmen, wat rond te lopen, in groepjes te praten en een drankje op een van de hotelterrassen te drinken. De ouderen zijn verzot op barbecues, die vooral tegen het vallen van de avond plaatsvinden, het zgn. 'moonlighten'. De bevolking ziet zich nu de mooiste stukken strand ontnomen door de zich steeds maar uitbreidende hotelbouw. Alhoewel de hotelstranden voor het publiek vrij toegankelijk zijn, hebben zij een ander karakter gekregen; minder natuurlijk en ongedwongen. Op de resterende, vrije gedeelten is het, met name rond Pasen, wanneer men uit traditie enkele dagen aan zee kampeert, bijzonder druk.

Vergroting van de draagfunctie van het binnenland voor recreatie zou de stranden ontlasten en tegemoet komen aan een steeds dringender behoefte, vooral van de plaatselijke bevolking, maar eveneens van de toeristen. Dit wordt door de Arubanen zelf ook zo aangevoeld, getuige de lokale initiatieven van de familie Adolfo Oduber tot het realiseren van een klein pretpark aan de noordzijde van de Hooiberg. Een in het begin van de zeventiger jaren gehouden enquête heeft uitgewezen, dat ruim 40\% van de Amerikaanse en Canadese bezoekers, die overwegend milieubewust zijn, wat van het eiland zelf wil zien. Toeristenbureau en D.E.C.O. beschikken op dit punt over nadere gegevens.

Sedert de komst van de Spanjaarden en de Hollanders aan het eind van de zestiende eeuw, heeft ontbossing plaatsgevonden. Dit hield verband met de aanleg van plantages, houtskool- en kalkbranden, alsmede de kap van commerciële houtsoorten, zoals verfhout (Haematoxylon brasiletto), pokhout (Guaiacum officinale), wayacá (Guaiacum sanctum) en mahok (Swietenia mahagoni). Daarbovenop kwam de invoer van ezels, geiten en schapen, die vrijelijk rondzwerven over het eiland. De cabrieten zijn sindsdien sterk verwilderd en vormen een ware plaag. Vrijwel alle oorspronkelijke vegetatie is verdwenen, resp. vervangen door geitbestendig, doornig struikge- 
was en velden schijfcactussen. Door de erosie spoelt veel vruchtbare grond weg naar zee.

De toenemende behoefte aan delfstoffen voor de bouwnijverheid heeft geleid tot omvangrijke ingrepen in de op het kleine eiland toch al beperkte landelijke gebieden. Uit economische motieven heeft het belang van goedkope steenslag voor wegenof huizenbouw steeds vooropgestaan bij de afweging van prioriteiten. Door de toenemende schaarste aan ongeschonden terreinen en de - vooral internationaal - groeiende waardering voor natuurwetenschappelijk, ecologisch en landschappelijk waardevolle gebieden, zoals het eiland Aruba die kent, moet behoud van het schaars wordende bezit aan natuurgebieden worden gesteld boven voornoemde zuiver-economische belangen van een beperkte groep van de bevolking.

Duidelijk is reeds gebleken, dat economische veranderingen een niet-gewenste aantasting van het milieu hebben meegebracht. Kritiek op natuurvernielingen volgt meestal pas op langere termijn, omdat de nadelen ervan zich eerst na geruime tijd doen gevoelen. Hierbij komt, dat de intellectuelen van Aruba, van wie men toch in de eerste plaats een kritisch geluid zou mogen verwachten, meestal gedurende vele jaren elders hebben gestudeerd en gewoond, waardoor zij zich minder sterk met hun eiland betrokken voelen als in dit opzicht wenselijk zou zijn. Dat van Nederlandse zijde meegedacht wordt over de verarming van Aruba's landschap en natuur, behoeft geen verbazing te wekken. Het N.R.C. Handelsblad van 23 juli 1977 vermeldt in een vette kop: 'Het Geuldal wordt vooral in de rest van Nederland gered.' Juist door het versneld 'kleiner worden' van onze aarde, spelen natuurproblemen heden ten dage in een wijder nationaal en internationaal verband.

Ondanks vier eeuwen roofbouw, welke sinds 1970 o.a. door ontgrondingen escaleert en thans wijd verspreid en op intensieve schaal plaats vindt, is op het eiland, nog veel uniek natuurschoon over.

Natuurgebieden

Als kleinste eiland van de Benedenwinden, met een hoge bevolkingsdichtheid, ondervindt Aruba in toenemende mate 
BEVOLKING EN MILIEU VAN ARUBA

druk op haar landschappelijk schoon en haar natuur. Verscheidene factoren zijn hieraan debet, zoals ruimtebeslag door verstedelijking, horizonvervuiling, verkeer, recreatie en ontgrondingen. Het is merkwaardig, dat op dit eiland, in tegenstelling tot het grotere Bonaire en Curaçao tot nu toe zo weinig aandacht wordt geschonken aan natuurbescherming.

Hieronder volgt een opsomming van enkele nog aanwezige landelijke gebieden.

Kudarebe aan de noordwestpunt is een fourageergebied voor pelikanen. Deze plaats wordt gedurende het week-end druk bezocht door de eilandelijke bevolking, die er in de auto doorrijdt. Men vangt hier ook koraalvisjes. Aansluitend het duingebied Californië, dat ongeveer een kilometer lang is en op zijn beurt wordt afgegrensd door het officiële, militaire oefenterrein Californië. Aan de westzijde van het eiland liggen de prachtige stranden Palm Beach en Eagle Beach, waarvan de mooiste stukken door de hotels zijn ingenomen. In de Paastijd staat dit hele gebied vol tenten en caravans van kamperende Arubanen en Venezolanen. Salinja Cerka heeft een moerasvegetatie. In de wintertijd fourageren daar trekvogels.

Landinwaarts liggen de historische commandeursgraven van Ponton en Seroe Patrishi; zij dateren van omstreeks 1700 . Vooral bij Ponton, een wijk van Oranjestad, is de omgeving op vele plaatsen vervuild door het storten van afval.

Nauwelijks te vergelijken met enig ander landschap in West Indië is het binnenland van Aruba, met zijn stapels diorietblokken, zoals van Ayo en Casibari, welke door verwering van het terrein zijn ontstaan. Op vele plaatsen zijn in uithollingen van deze blokken Indiaanse rotstekeningen gevonden.

Een uniek natuurmonument vormde de Seroe Canashito. Helaas werd deze kalksteenheuvel reeds bijna geheel afgegraven voor het winnen van steenslag. Het is de bedoeling dat de schilderachtige steile noordkant - waarin zich ook nog rotstekeningen bevinden - zal blijven gespaard; maar nu reeds ziet een luchtreiziger slechts een witte stoffige vlek op de plaats waar zich vroeger een uniek stukje Arubaans landschap bevond.

Vanaf Seroe Plat heeft men een goed uitzicht op de omgeving, welke overigens grondig is vernield. In de aangrenzende Seroe Cristal bevinden zich nog oude mijnschachten; hier vindt men ook nog bergkristal. Het afwisselend gebied van Andicuri, aan de noordkust, heeft een cocosplantage welke aan de zee grenst. Het is bij de bevolking een geliefde plaats voor barbecuen en zwemmen. Meer naar het westen ligt de $n a$ tuurlijke brug, het uit toeristisch oogpunt gezien meest krakteristieke natuurmonument van het eiland. Hier bevindt zich een uitspanning met een uitgesproken couleur locale, waar 's-zondags de Arubanen met inheemse instrumenten, zoals ' $\mathrm{Ca}$ 'i orgel, tambu en wiri, muziek maken.

Voor de zuidkust liggen lange koraalriffen. Het rif bij Cas di Paloma is drie kilometer lang, dat bij Barcadera is veel smaller en heeft een lengte over ongeveer twee kilometer. Deze ongeschonden riffen zijn begroeid met mangroven. Het is een broedgebied voor vogels. Het Spaans Lagoen is een door mangroven omgeven kreek, waarachter een wijd dal ligt, begrensd door de rünes van de goudsmelterij Balashi, de Franse Pas met haar aan weerszijden hoogoprijzende rotswanden - waartussen zwermen groene parkieten vliegen, welk dal wordt afgesloten door een plantage met palmbomen. Het dal wordt doorsneden door een verharde autoweg. Isla di Oro is door een houten voetpad dwars door een breed mangrovenbos en over het ondiepe zeewater 


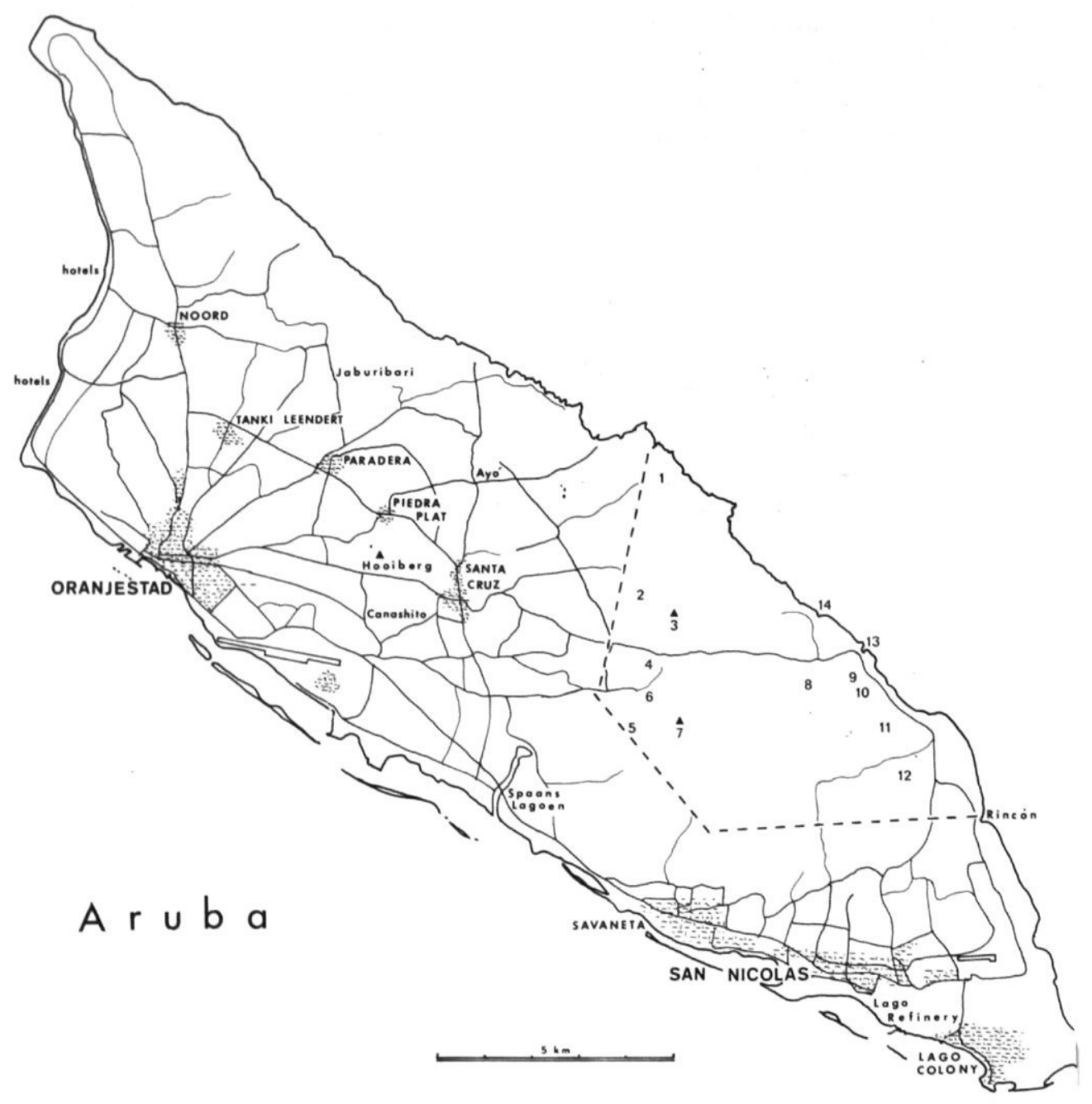

Fig. 8. Schetskaartje van Aruba waarop de omgrenzing staat aangegeven van het terrein dat in deze publicatie als een te beschermen gebied wordt aanbevolen en dat een uitbreiding betekent van 'Nationaal Park Arikok' (1-3, 13-14). - 1: Cocospalmplantage van Daimari met strandjes. 2: Indiaanse rotstekeningen van Arikok. 3: Top van de Arikok, $188 \mathrm{~m}$, uitzicht. 4: Oude goudmijn van Miralamar. 5: Tuin van Masiduri. 6: Cocospalmenplantage. 7: Top van de Jamanota, $188 \mathrm{~m}$, uitzicht. 8: Oude plantage van Rooi Prins, adobehuis, mooie rotswand. 9: Grot van Fontein met rotstekeningen. 10: Chinese groententuin bij de bron van Fontein. 11: Grot van Quadirikiri. 12: Huliba Cave en Tunnel of Love. 13: Boca Prins met strand en duinen. 14: Strand van Dos Playa, grillig kustgebied. 
met de vaste wal verbonden. Het is een prachtige omgeving. Door overmatig bespuiten is in het mangrovenbos het evenwicht tussen vissen en muggenlarven ten gunste van de 'sangudos' verschoven.

Seroe Colorado heeft enkele mooie strandjes, en imposante rotspartijen. Naar het noorden toe ligt het desolate en afwisselende kustgebied tussen Rincón en Daimari met haar woeste achterland. Zie daarover de nu volgende bespreking van de lokale plannen 'Natuurpark Jamanota.'

In onderstaand schema zijn de natuurgebieden samengevat vanuit de optiek van recreatie. Maar er zijn een aantal factoren welke de aantrekkelijkheid, zeker voor herhaald bezoek beperken. Uit de opstelling blijkt, afgezien van natuurschoon e.d., dat het kustgebied tussen Rincón en Daimari met het achter-

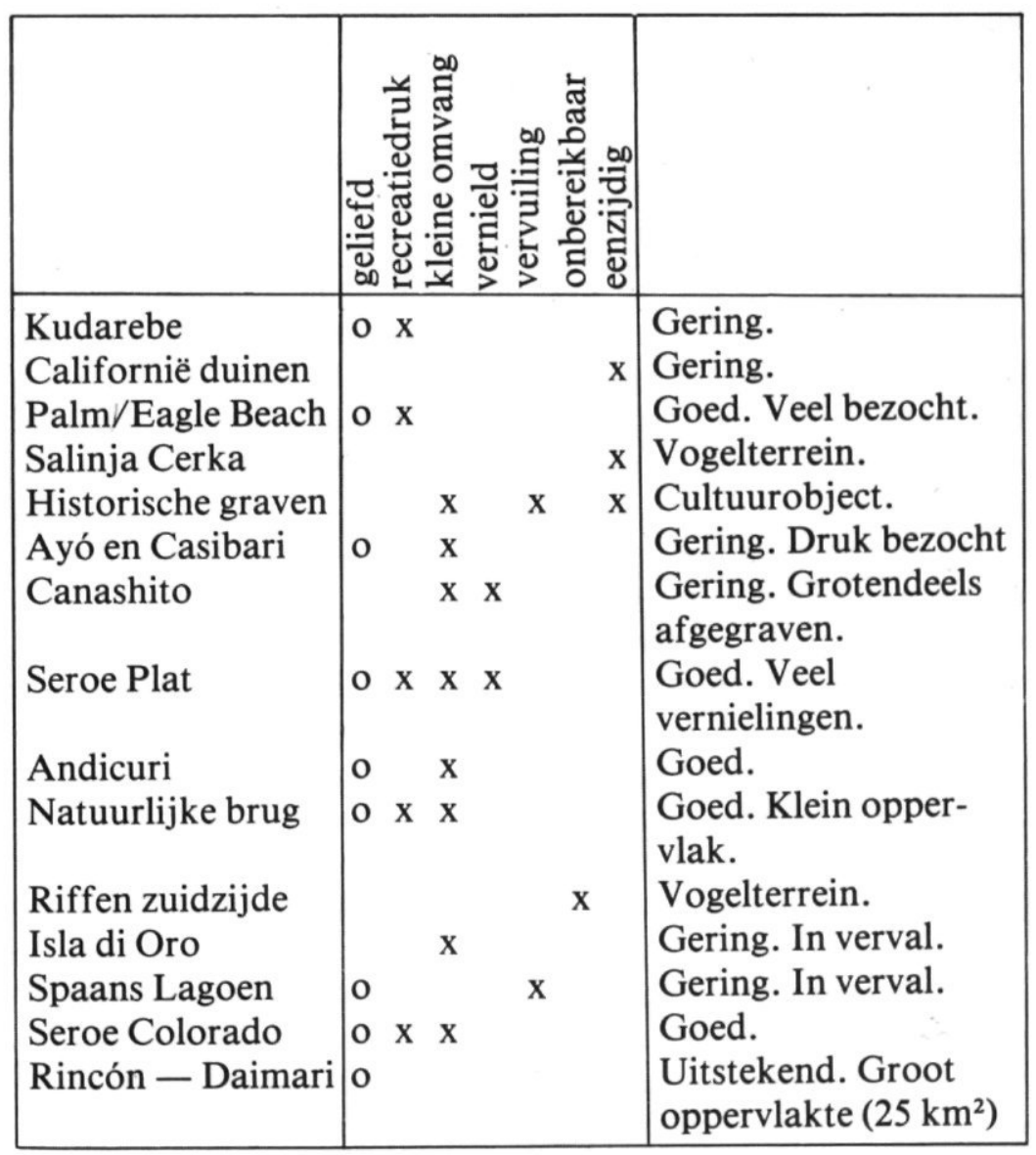


land, de gunstigste perspectieven biedt voor aanvullende recratiemogelijkheden.

Zowel het Eilandsbestuur als de Aruba Commissie van de Stichting Nationale Parken Nederlandse Antillen (Stinapa) beraden zich over de wenselijkheid om een Nationaal Park Jamanota in te richten. Het Ingenieursbureau Plan D2 heeft terzake een rapport aan het Bestuurscollege uitgebracht.

Het genoemde geaccidenteerde terrein - begrensd door Daimari, Shete, Ceru Blancu, Ranca Piedra, Rincón en de zee - heeft een oppervlakte van 2.500 hectare (zie fig. 8). Het reeds bestaande Natuurgebied Arikok bevat Aruba's oudste formatie van vulkanische gesteenten: diabazen, diabaastuffen en diabaasconglomeraten. Het gedeelte ten westen van de Jamanota heeft dioritische gesteenten - ongeveer 60 millioen jaar oud - die door intrusie van magma in de oudere formatie is ontstaan. Voorts bevinden er zich uitgestrekte koraalkalterrassen met een aantal grotten (Fontein, Quadirikiri, Tunnel of Love, Huliba Cave) die een bezoek overwaard zijn. De Grot van Fontein - dicht bij een bekende bron gelegen - is de oudste vindplaats van Indiaanse petrographieën. Speciale aandacht verdient het boeiende landschap bij Boca Prins, waar men nog duinen aantreft en waar een schilderachtige steilrand van het kalksteenplateau een hofje met cocospalmen begrensde.

De verscheidenheid van landschap en microklimaat brengt grote verschillen in begroeiing met zich mede. Langs de kust een halofytische strandvegetatie, meer landinwaarts een xerophytisch plantendek. Afgezien van het voorkomen van enkele soorten die tot de Benedenwindse Eilanden zijn beperkt, is de cactusvegetatie van Aruba merkwaardig omdat er zóveel tot dit gebied beperkte Melocactus-vormen zijn beschreven, dat Aruba in de botanische wereld als een soort scheppingscentrum voor melocactus-soorten bekend staat.

Bescherming van dit uitzonderlijk mooie en bijzondere landschap is geboden. Als men wacht tot de bevolking milieubewust is geworden - hetgeen zeker zal gebeuren, zoals voorbeelden van welvarende volkeren elders leren - is het te laat. 
Het gehele terrein - ook het reeds tot natuurgebied verklaarde Arikok-gedeelte - wordt thans met meer dan twintig trucks, bulldozer en dynamiet, op grote schaal bedorven. Op dit ogenblik concentreren deze natuurvernielingen zich bij Baranca Kasioenti, vlak bij de indrukwekkende steilrand van het kalksteenplateau achter Rooi Prins. Van dit eens zo fraaie natuurgebied is, mede gezien de verderopliggende en zich voortdurend uitbreidende officiële steengroeve, niet veel meer over.

Aruba's sterk verarmde landschap behoeft herbebossing, waarbij dan tevens toeristische attracties kunnen worden ingebouwd, zoals een door bellísima omzoomde weg, bloeiende aloëveldjes, cactustuinen en paden die door agaven en zuilcactussen worden begrensd. Men moet niet vergeten dat - in elk geval voor de toerist - het karakter van Aruba, waarschijnlijk meer dan dat van enig ander eiland van de Antillen, door cactussen, agaven en aloës wordt bepaald.

Ieder die Aruba kent zal bij het woord 'herbebossing' denken aan de vele experimenten welke weinig of geen positieve resultaten hebben opgeleverd. Afgezien van de vele andere eisen waaraan hierbij moet worden voldaan, zullen het watervraagstuk en het geitenprobleem allereerst om een oplossing vragen. Een overzicht van de mogelijkheden om deze aanplantingen te doen met plantensoorten die door hun voorkomen op de eilanden hun bruikbaarheid reeds hebben bewezen, heeft frater Arnoldo Broeders ons reeds in zijn Handleiding (1967) gegeven.

\section{CONCLUSIES}

- met argumenten voor een Nationaal park cursief gedrukt -

De bevolkingsgroei is in vergelijking met soortgelijke regio's drastisch verminderd. Het eiland telt verhoudingsgewijs veel 'tieners', wat inhoudt, dat voor het komende decennium een behoorlijke toename van de beroepsbevolking en van het aantal jonge gezinnen verwacht mag worden. Deze zullen met hun kinderen additionele druk uitoefenen op het milieu, namelijk voor woonruimte en recreatie. 
De bevolkingsdichtheid per $\mathrm{km}^{2}$ van 321 is hoog, temeer daar de woongebieden zich alle bevinden bezuiden de waterscheiding 'Alto Vista - Babijn - Ayó - Shete - Jamanota - Ranca Piedra', een gebied, dat ongeveer $2 / 3$ van het eiland beslaat, derhalve 481 mensen per $\mathrm{km}^{2}$ tellende. Dit laatste cijfer geeft een onderwaardering van de bevolkingsdruk, omdat geen rekening is gehouden met de toeristen. Het gevaar is niet denkbeeldig, dat bedrijven, zoals kippefarm en horeca gevestigd zullen worden in de nog rustige natuurgebieden.

De aan de voet versmalde bevolkingspiramide, de grote bevolkingsdichtheid, de vergelijking van de vruchtbaarheid met die in overeenkomstige regio's, toenemende criminaliteit en alcoholgebruik, wijzen alle in de richting van een onacceptabel geachte bevolkingsdruk. Door de goede scholing en de grote welvaart, al zijn de vruchten daarvan minder gelijkelijk verdeeld dan in Nederland, is het ruimtegebrek intensiever dan in gebieden met een arme en ook minder mobiele bevolking. Zeer duidelijk treedt het toenemende ruimtebeslag aan de dag in ontgrondingen, de groei van de buitendistricten, lintbebouwing, de druk op recreatiegebieden, vooral in het Paasseizoen en de zich doorzettende floristische- en faunistische verarming.

De mogelijkheden tot agrarische activiteiten zijn zeer beperkt door de geringe regenval van gemiddeld $443,8 \mathrm{~mm}$ en de fluctuaties daarin over de jaren (zie fig. 1). Daarenboven is er bijna geen grondwater, omdat de bodemstructuur daarvoor niet gunstig is, terwijl de verdamping van oppervlaktewater onder invloed van de vrijwel steeds schijnende zon en harde passaatwind, jaarlijks een veelvoud van de regenval bedraagt, namelijk ongeveer $3.000 \mathrm{~mm}$. Genoemde factoren bemoeilijken uiteraard niet alleen de landbouw, doch maken eveneens de inlandse natuurgebieden kwetsbaar.

Door het goed lonenende werk bij Lago, hotels en overheid, zijn agrarische bezigheden economisch onaantrekkelijk, terwijl die bovendien veel zwaarder zijn. De percelen zijn klein van omvang, hetgeen een belemmering vormt voor mechanisatie. Om het beoefenen van het boerenbedrijf aantrekkelijker te maken zijn noodzakelijk: mogelijkheid en faciliteiten voor 
irrigatie, het zich specialiseren op hoogwaardige tuinbouwproducten, het zoveel mogelijk door middel van moderne technieken verlichten van de arbeidsomstandigheden, en vóór alles motivatie. Interactie tussen landbouw (watervergaring, gewassen) en natuurschoon wordt noodgedwongen gemist.

Sinds de vijftiger jaren is de prijs van het exportprodukt aloïne - een aloëderivaat - gedaald. Pogingen om het snijproces te mechaniseren zijn op niets uitgelopen. De aloëboeren sterven uit, hetgeen in zekere zin ontbossing betekent, alsmede het verdwijnen van een toeristische bezienswaardigheid.

TABEL 12

Ontwikkeling van het aantal manjaren (werknemers) op Aruba

\begin{tabular}{llrrrl}
\hline I.S.I.C. & sector & \multicolumn{1}{c}{1972} & \multicolumn{1}{c}{1974} & mutatie & $(\%)$ \\
\hline I/III & Landbouw/industrie & 2.129 & 2.120 & -9 & $(-0,4)$ \\
IV & Utiliteitsbedrijven & 414 & 420 & 6 & \\
V & Bouwnijverheid & 2.017 & 2.736 & 719 & $(35,7)$ \\
VI/IX & Dienstensector & 6.755 & 7.517 & 762 & $(11,3)$ \\
\hline & TOTAAL & 11.315 & 12.793 & 1.478 & $(13,1)$ \\
\hline
\end{tabular}

Uit tabel 12 blijkt dat de bouwnijverheid voor wat betreft de werkgelegenheid de grote groeier is. $\mathrm{Zij}$ is het die de steenslag betrekt. Daarom zal waarschijnlijk alléén beperking van de steenbreek tot enkele plaatsen succes hebben. Opvallend is tevens de sterke groei van de dienstensector; immers de bouwnijverheid is hiervan deels een afgeleide. Het belang van de industrie voor de werkgelegenheid is daarentegen iets afgenomen, waardoor de economische structuur nog eenzijdiger dreigt te worden dan zij reeds is.

Op langere termijn bezien vertoont de 'toeristenindustrie' in vele landen een grillig beeld. De economische activiteiten op Aruba concentreren zich juist hierop. De overige dienstverlening, alsmede de bouw, profiteren van het multiplier-effect. Gemeten naar arbeidsvolume voor het jaar 1974, ontstaat het volgende totaalbeeld: 


$$
\begin{aligned}
& \text { — primaire sector :landbouw, visserij } \quad 0,3 \% \\
& \text { - secundaire sector: industrie } \quad 9,4 \% \text {. } \\
& \text { openbare nutsbedrijven } 1,9 \% \text { 24,3\% } \\
& \text { bouwnijverheid } \quad 13,0 \% \\
& \begin{array}{llr}
- \text { tertiaire sector } & \text { : particuliere bedrijven } & 51,1 \% \\
& \text { overheid (incl. arb. res.) } & 24,3 \%
\end{array} \mid 75,4 \%
\end{aligned}
$$

De economie is door haar eenzijdige structuur sterk afhankelijk van het toerisme. De concurrentiepositie daarvan zou versterkt worden door vergroting van het toeristisch kapitaal i.c. natuurschoon. Agrarische activiteiten en verbetering van de hydrologische omstandigheden, dragen bij tot het landschapsschoon, terwijl zij daarnaast de economie iets minder eenzijdig zouden maken. Aruba's potentiële positie als trait-d'union tussen Noord- en Zuid-Amerika wordt mijns inziens onderschat. Met name ware hierbij te denken aan het inspelen op de huidige 'groeier' binnen de westerse economieën, namelijk de communicatie industrie. De klassieke industrieën verhuizen thans voor een groot deel naar ontwikkelingslanden.

Het milieu is sterk verarmd door vier eeuwen roofbouw, die sinds 1970 is geëscaleerd door grootschalige ontgrondingen. Aruba bezit een aantal natuurgebieden, waarvan alléén de kuststrook Rincón - Daimari plus achterland de mogelijkheid biedt tot inrichting als natuur- of landschapspark. Hiermede zijn zowel lokale als interlokale belangen gediend.

Omdat ontgrondingen zich hebben verplaatst van terreinen bij Santa Cruz en Babijn naar voornoemd, wat betreft de omvang betreft beperkt, natuurgebied, is actie om dit te behouden dringend gewenst; omdat namelijk met het ontginnen van dit terrein de mogelijkheid van een 'natuurpark' op Aruba voorgoed verkeken zou. zijn. Het is derhalve zaak voor de Arubanen om zich goed te realiseren wat het eindresultaat is van een strategie van 'niets ondernemen'. Het huidige, schrale landschap zou overigens véél meer te bieden hebben, ware het niet, dat het eeuwenlang is leeggegeten en leeggehaald door respectievelijk cabrieten en ontbossers. De natuur heeft beide, zij het sterk gehavend, weten te overleven. Steenbreek echter is vernietigend. 


\section{LITERATUUR}

Antersijn, G.M.: Bevolkinsprognose 1974 - 2000 voor Curaçao en Aruba, invloeden hierop van demografische factoren. Aruba, januari 1976.

Arnoldo Broeders, Fr. M.: Handleiding tot gebruik inheemse en ingevoerde planten op Aruba, Bonaire en Curaçao. St. Augustinus, Curaçao 1967.

Bevolking en Arbeid. Aruba, D.E.C.O., aug. 1974.

Bradfield, Richard: The agriculture and agricultural potentialities of Aruba. Soil Technology, Cornell Un., Ithaca, N.Y., 1964.

Encyclopedie van de Nederlandse Antillen, Elsevier Ned. N.V., 1969.

Erkelens, J.: Een berekeningsmethode voor de logistische curve. Statistica neerlandica 22 , no. 3, 1968.

Hartog, Johan: Aruba past and present. De Wit, Oranjestad, Aruba, 1961.

Henriquez, P.C.: Monumentenzorg en natuurbeheer. Cultureel Mozaïek van de Nederlandse Antillen. De Walburg Pers Zutphen, 1977, p. 227-261.

Kok, Michiel: De economische structuur van de Nederlandse Antillen. St. Augustinus, Curaçao.

Korps Politie Nederlandse Antillen, Commissariaat Aruba. Jaarverslag 1973 en 1975.

Luidens, Felix: The impact of stay-over tierism on the economy of Aruba. Inter Amer. Univ., Puerto Rico, July 1975.

Mörzer Bruyns, M.F.: Natuurbehoud en natuurbeheer op de Nederlandse Antillen. Rijksinst. Natuurbeheer, Zeist, 1969.

Moulin, P.L. de: Schets van een ontwikkelingsplan Aruba. D.E.C.O., Aruba, febr. 1976.

Nationale Rekeningen 1975. Centr. Bureau Statistiek, Staatsuitgeverij, 1976.

Proceedings of the first Aruban and Antillean Congress on Alcoholism. Aruba, sept. 1970.

Ruimtelijk Structuurplan (Aruba). Adviesbureau Arnhem b.v., 1975.

Statistiek arbeidsvolume en loonsommen in 1972. D.E.C.O., Aruba, aug. 1974. Idem 1973.

Drs A.G.M. Claassen

Landréstraat 366

's-Gravenhage 